\title{
Effects of high nutrient intake on the growth performance, intestinal morphology and immune function of neonatal intra-uterine growth-retarded pigs
}

\author{
Fei Han, Liang Hu, Yue Xuan, Xuemei Ding, Yuheng Luo, Shiping Bai, \\ Shuying He, Keying Zhang* and Lianqiang Che* \\ Institute of Animal Nutrition, Sichuan Agricultural University, No. 211, Huimin Road, Wenjiang District, \\ Chengdu, Sichuan 611130, People's Republic of China
}

(Submitted 9 October 2012 - Final revision received 14 March 2013 - Accepted 15 March 2013 - First published online 19 April 2013)

\section{Abstract}

Intra-uterine growth-retarded (IUGR) neonates have shown an impairment of postnatal intestinal development and function. We hypothesised that the immune function of IUGR neonates might be affected by increased nutrient intake (NI) during the suckling period. Therefore, we investigated the effects of high NI (HNI) on the growth performance, intestinal morphology and immunological response of IUGR and normal-birth weight (NBW) piglets. A total of twelve pairs of IUGR and NBW piglets ( $7 \mathrm{~d}$ old) were randomly assigned to two different nutrient-level formula milk groups. After $21 \mathrm{~d}$ of rearing, growth performance, the composition of peripheral leucocytes, serum cytokines and intestinal innate immune-related genes involved in the Toll-like receptor (TLR)-4-myeloid differentiation factor $88-\mathrm{NF}-\mathrm{\kappa} B$ pathway were determined. The results indicated that IUGR decreased the average daily DM intake (ADMI) and the average daily growth (ADG). However, the ADMI and ADG were increased by HNI, irrespective of body weight. Likewise, serum cytokines (TNF- $\alpha$ and IL- $1 \beta$ ) and ileal gene expressions (TLR-4, TLR-9, TRAF-6 and $I L-1 \beta$ ) were lower in IUGR piglets, whereas HNI significantly increased blood lymphocyte percentage and serum IL-10 concentrations, but decreased neutrophil percentage, serum IL-1 $\beta$ concentrations and ileal gene expressions $(N F-\kappa B$ and $I L-1 \beta)$. Furthermore, IUGR piglets with HNI exhibited lower serum concentrations of TNF- $\alpha$ and IL-1 $\beta$ than NBW piglets, and these alterations in the immune traits of IUGR piglets receiving HNI were accompanied by decreasing ileal gene expressions of $T L R-4, T L R-9, N F-\kappa B$ and $I L-1 \beta$ that are related to innate immunity. In conclusion, the present findings suggest that increased NI during the suckling period impaired the immune function of neonatal piglets with IUGR.

Key words: Intra-uterine growth-retarded pigs: Nutrient intakes: Immune function: Intestines

Intra-uterine growth retardation (IUGR) is usually defined as impaired growth and development of the embryo and/or its organs during gestation ${ }^{(1)}$. In humans, IUGR has been observed in about $23.8 \%$ of newborns and approximately thirty million babies worldwide suffer from IUGR every year $^{(2)}$. Previous studies have shown that IUGR neonates are associated with higher postnatal morbidity and mortality ${ }^{(3,4)}$. Due to developmental and growth restriction, IUGR neonates often appear immature with regard to the digestive and immune systems compared with their normal counterparts ${ }^{(5,6)}$. For example, changes in histopathology and thymus size have been observed ${ }^{(7,8)}$, and lower numbers of $\mathrm{T}$ cells in the thymus $^{(9)}$ as well as an abnormal cytokine profile in serum $^{(10)}$ and the intestine ${ }^{(5,10,11)}$ have been reported in IUGR neonates.
In order to achieve catch-up growth, human IUGR neonates are generally fed a high-protein formula ${ }^{(12)}$ or a special formula containing a high density of nutrients ${ }^{(13)}$. However, catch-up growth in the first few weeks of postnatal life renders IUGR neonates to an increased risk of the metabolic syndrome such as obesity or other obesity-related diseases in later life $\mathrm{e}^{(14)}$. In addition, evidence in poultry has shown that high nutrient density could decrease the immune function ${ }^{(15)}$, whereas decreased feed intake can optimise the immune system $^{(16)}$. Although it has been widely reported that IUGR impairs intestinal development and function, the intestinal innate immune response and the role of early high nutrient intake (HNI) in regulating innate immunity are still vague. Because of the physiological and genomic similarities between pigs and humans ${ }^{(17)}$, the pig has been recognised as an ideal

Abbreviations: ADMI, average daily DM intake; ANI, adequate nutrient intake; BW, body weight; HNI, high nutrient intake; IUGR, intra-uterine growth retardation; NBW, normal birth weight; NI, nutrient intake; TLR, Toll-like receptor; VCR, villous height:crypt depth ratio. 
using standard paraffin embedding procedures. A total of five intact, well-oriented crypt-villus units were selected in triplicate for each intestine of piglets. Villous heights and crypt depths were measured using an image processing and analysis system (Optimus software version 6.5; Media Cybergenetics).

\section{Total RNA extraction and real-time RT-PCR}

Total RNA was isolated from ileal samples using TRIzol (catalogue no. 15 596-026; Invitrogen). RNA quality was verified by both agarose gel (1\%) electrophoresis and spectrometry (A260/A280, Beckman DU-800; Beckman Coulter, Inc.). Realtime RT-PCR was performed in duplicate to amplify the target gene and the reference gene of the ileum using the one-step SYBR ${ }^{\circledR}$ PrimeScript $^{\mathrm{TM}}$ RT-PCR kit II (catalogue no. DRR086A; Takara). Briefly, the reaction mixture (10.0 $\mu \mathrm{l})$ contained $5.6 \mu \mathrm{l}$ of a freshly premixed one-step SYBR Green RT-PCR Master mix and a PrimeScript ${ }^{\mathrm{TM}}$ Enzyme Mix, $0.8 \mu \mathrm{l}$ of the primer pair and $3.6 \mu \mathrm{l}$ RNA template that contained about $150 \mathrm{ng}$ RNA. PCR consisted of one cycle at $42^{\circ} \mathrm{C}$ for $5 \mathrm{~min}$, one cycle at $95^{\circ} \mathrm{C}$ for $10 \mathrm{~s}$ and forty cycles at $95^{\circ} \mathrm{C}$ for $5 \mathrm{~s}$ and $60^{\circ} \mathrm{C}$ for $34 \mathrm{~s}$, followed by a dissociation step at $95^{\circ} \mathrm{C}$ for $15 \mathrm{~s}, 60^{\circ} \mathrm{C}$ for $60 \mathrm{~s}$ and $95^{\circ} \mathrm{C}$ for $15 \mathrm{~s}$. To confirm specific amplification, melt curve analysis was performed (ABI 7900HT; Applied Biosystems).

Relative mRNA abundance was determined using the $\Delta$ cycle threshold $\left(\Delta C_{\mathrm{t}}\right)$ method, as outlined in the protocol of Applied Biosystems. In brief, a $\Delta C_{\mathrm{t}}$ value is the $C_{\mathrm{t}}$ difference between the target gene and the reference gene $\left(\Delta C_{\mathrm{t}}=C_{\mathrm{t}}^{\mathrm{target}}-C_{\mathrm{t}}^{\text {reference }}\right)$. For each of the target genes, the $\Delta \Delta C_{\mathrm{t}}$ values of all the samples were calculated by subtracting the average $\Delta C_{\mathrm{t}}$ of the corresponding IUGR/ANI group. The $\Delta \Delta C_{\mathrm{t}}$ values were then converted to fold differences by raising
2 to the power $-\Delta \Delta C_{\mathrm{t}}\left(2^{-\Delta \Delta C_{\mathrm{t}}}\right)$. Further details on relative gene expression analysis have been described previously ${ }^{(21)}$. Primers (Table 2) for the assayed genes and the reference gene were designed using Primer Express 3.0 (Applied Biosystems).

\section{Statistical analysis}

Data of blood leucocytes and serum cytokines were analysed as repeated measures using the MIXED procedure of Statistical Product and Service Solutions 17.0 (SPSS, Inc.) according to the following model:

$$
\begin{aligned}
Y_{i j k l}= & \mu+\alpha_{i}+\beta_{j}+(\alpha \beta)_{i j}+U_{k}+\omega_{l}+(\alpha \omega)_{i l}+(\beta \omega)_{j l} \\
& +(\alpha \beta \omega)_{i j l}+\varepsilon_{i j k l},
\end{aligned}
$$

where $\mu$ is the mean; $\alpha_{i}$ is the effect of BW ( $i=$ IUGR, NBW); $\beta_{j}$ is the effect of NI ( $j=\mathrm{ANI}, \mathrm{HNI}) ; \alpha \beta_{i j}$ is the interaction between $\mathrm{BW}$ and NI; $U_{k}$ is the litter $(k=1,2, \ldots, 12) ; \omega_{l}$ is the time (days 14 and 21$), \alpha \omega_{i l}$ is the interaction between BW and time; $\beta \omega_{j l}$ is the interaction between NI and time; $\alpha \beta \omega_{i j l}$ is the interaction between BW, NI and time; $\varepsilon_{i j k l} \sim N\left(0, \sigma^{2}\right)$ represents the random error. Data of intestinal morphology were also analysed as repeated measures according to the model; however, $\omega_{l}$ here refers to the segment (duodenum, jejunum and ileum), $\alpha \omega_{i l}$ refers to the interaction between BW and segment, $\beta \omega_{j l}$ refers to the interaction between NI and segment and $\alpha \beta \omega_{i j l}$ refers to the interaction between BW, NI and segment. Data on growth performance, organ indices and gene expressions were analysed according to the model, but omitting the effect of time and the interaction between time, BW and NI. Results are presented as means with their standard errors. Differences between groups were analysed using the general linear model procedure followed by Duncan's test. $P<0.05$ was considered as statistically significant.

\begin{tabular}{|c|c|c|c|}
\hline Genes & Primer sequence $\left(5^{\prime}-3^{\prime}\right)$ & Product (bp) & GenBank accession \\
\hline$T L R-2$ & $\begin{array}{l}\text { Forward: TCGAAAAGAGCCAGAAAACCAT } \\
\text { Reverse: CTTGCACCACTCGCTCTTCA }\end{array}$ & 58 & NM213761 \\
\hline$T L R-4$ & $\begin{array}{l}\text { Forward: AGAAAATATGGCAGAGGTGAAAGC } \\
\text { Reverse: CTTCGTCCTGGCTGGAGTAGA }\end{array}$ & 64 & GQ304754 \\
\hline$T L R-9$ & $\begin{array}{l}\text { Forward: AATCCAGTCGGAGATGTTTGCT } \\
\text { Reverse: GACCGCCTGGGAGATGCT }\end{array}$ & 79 & AY859728 \\
\hline MyD88 & $\begin{array}{l}\text { Forward: GTGCCGTCGGATGGTAGTG } \\
\text { Reverse: TCTGGAAGTCACATTCCTTGCTT }\end{array}$ & 65 & NM001099923 \\
\hline TRAF-6 & $\begin{array}{l}\text { Forward: GCTGCATCTATGGCATTTGAAG } \\
\text { Reverse: CCACAGATAACATTTGCCAAAGG }\end{array}$ & 70 & AJ606305.1 \\
\hline$N F-\kappa B$ & $\begin{array}{l}\text { Forward: TGCTGGACCCAAGGACATG } \\
\text { Reverse: CTCCCTTCTGCAACAACACGTA }\end{array}$ & 60 & АК348766.1 \\
\hline SIGIRR & $\begin{array}{l}\text { Forward: ACCTGGGCTCCCGAAACTAC } \\
\text { Reverse: GTCATCTTCTGACACCAGGCAAT }\end{array}$ & 62 & AK239384.1 \\
\hline TOLLIP & $\begin{array}{l}\text { Forward: CCCGCGCTGGAATAAGG } \\
\text { Reverse: CATCAAAGATCTCCAGGTAGAAGGA }\end{array}$ & 74 & AK239879.1 \\
\hline$I L-1 \beta$ & $\begin{array}{l}\text { Forward: TCTGCCCTGTACCCCAACTG } \\
\text { Reverse: CCAGGAAGACGGGCTTTTG }\end{array}$ & 64 & NM214055.1 \\
\hline$\beta$-Actin & $\begin{array}{l}\text { Forward: GGCGCCCAGCACGAT } \\
\text { Reverse: CCGATCCACACGGAGTACTTG }\end{array}$ & 66 & DQ845171.1 \\
\hline
\end{tabular}

Table 2. Primer sequences of the target and reference genes

TLR, Toll-like receptor; MyD88, myeloid differentiation factor 88; TRAF-6, TNF receptor-associated factor 6; SIGIRR single Ig IL-1-related receptor; TOLLIP, Toll-interacting protein. 
Table 3. Effects of the level of nutrient intake on the growth performance of intra-uterine growth-retarded (IUGR) and normal-birth weight (NBW) neonates

(Mean values with their standard errors)

\begin{tabular}{|c|c|c|c|c|c|c|c|c|}
\hline \multirow[b]{2}{*}{ Parameters } & \multicolumn{2}{|c|}{ ANI } & \multicolumn{2}{|c|}{$\mathrm{HNI}$} & \multirow[b]{2}{*}{ SEM } & \multicolumn{3}{|c|}{$P$} \\
\hline & IUGR & NBW & IUGR & NBW & & BW & $\mathrm{NI}$ & $\mathrm{BW} \times \mathrm{NI}$ \\
\hline Initial weight $(\mathrm{kg})$ & $1 \cdot 68^{\mathrm{a}}$ & $2 \cdot 76^{\mathrm{b}}$ & $1 \cdot 68^{\mathrm{a}}$ & $2 \cdot 80^{\mathrm{b}}$ & 0.19 & $<0.001$ & 0.742 & 0.758 \\
\hline Final weight (kg) & $5 \cdot 34^{a}$ & $7 \cdot 74^{c}$ & $6 \cdot 32^{\mathrm{b}}$ & $9 \cdot 01^{d}$ & 0.64 & $<0.001$ & 0.001 & 0.620 \\
\hline Net weight gain $(\mathrm{kg})$ & $3.66^{\mathrm{a}}$ & $4.99^{\mathrm{b}}$ & $4 \cdot 62^{b}$ & $6 \cdot 14^{c}$ & 0.55 & $<0.001$ & 0.001 & 0.722 \\
\hline \multicolumn{9}{|l|}{$A D G(g / d)$} \\
\hline Days $0-7$ & $152^{\mathrm{a}}$ & $225^{\mathrm{b}}$ & $180^{\mathrm{a}}$ & $233^{b}$ & 33 & $<0.001$ & 0.261 & 0.538 \\
\hline Days $7-14$ & 152 & 163 & 146 & 174 & 40 & 0.327 & 0.902 & 0.669 \\
\hline Days $14-21$ & $218^{a}$ & $324^{b}$ & $335^{\mathrm{b}}$ & $496^{c}$ & 61 & $<0.001$ & $<0.001$ & 0.311 \\
\hline Days $0-21$ & $174^{\mathrm{a}}$ & $237^{b}$ & $221^{\mathrm{b}}$ & $292^{c}$ & 26 & $<0.001$ & 0.001 & 0.722 \\
\hline \multicolumn{9}{|l|}{ ADMI $(g / d)$} \\
\hline Days $0-7$ & $114^{\mathrm{a}}$ & $150^{b}$ & $146^{\mathrm{b}}$ & $196^{c}$ & 20 & $<0.001$ & $<0.001$ & 0.416 \\
\hline Days $7-14$ & $108^{\mathrm{a}}$ & $153^{\mathrm{b}}$ & $164^{\mathrm{b}}$ & $247^{c}$ & 17 & $<0.001$ & $<0.001$ & 0.021 \\
\hline Days $14-21$ & $201^{a}$ & $258^{b}$ & $318^{\mathrm{c}}$ & $377^{d}$ & 35 & 0.001 & $<0.001$ & 0.928 \\
\hline Days $0-21$ & $142^{a}$ & $187^{b}$ & $210^{\mathrm{b}}$ & $272^{c}$ & 22 & $<0.001$ & $<0.001$ & 0.393 \\
\hline \multicolumn{9}{|l|}{$\mathrm{FCR}^{*}$} \\
\hline Days $0-7$ & $0.77^{\mathrm{a}}$ & $0.67^{a}$ & $0.83^{a, b}$ & $0.94^{\mathrm{b}}$ & 0.12 & 0.932 & 0.006 & 0.073 \\
\hline Days $7-14$ & $0.76^{\mathrm{a}}$ & $0.96^{a, b}$ & $1 \cdot 17^{\mathrm{b}}$ & $1.44^{c}$ & 0.18 & 0.007 & $<0.001$ & 0.637 \\
\hline Days $14-21$ & 0.96 & 0.81 & 0.99 & 0.77 & 0.17 & 0.046 & 0.947 & 0.685 \\
\hline Days $0-21$ & $0 \cdot 82^{a, b}$ & $0.79^{a}$ & $0.97^{\mathrm{c}}$ & $0.93^{b, c}$ & 0.08 & 0.466 & 0.003 & 0.920 \\
\hline
\end{tabular}

ANI, adequate nutrient intake; HNI, high nutrient intake; BW, body weight; NI, nutrient intake; ADG, average daily gain; ADMI, average daily DM intake; FCR, feed conversion ratio.

a,b,c,d Mean values within a row with unlike superscript letters were significantly different $(P<0.05)$.

${ }^{*}$ FCR was calculated by dividing the ADMI by its corresponding ADG.

\section{Results}

\section{Growth performance}

In the present study, regardless of the NI, the initial BW, final $\mathrm{BW}$ and $\mathrm{BW}$ gain of IUGR piglets were lower $(P<0 \cdot 001)$ than those of NBW neonates (Table 3). However, relative to NBW piglets with ANI, IUGR piglets receiving HNI had a comparable BW gain, but the final BW was still lower $(-18.3 \%$, $P<0.05$ ). Regardless of the NI, IUGR piglets had a lower $(P<0.001)$ average daily gain during the 1 st and 3 rd weeks compared with NBW piglets; as a result, the overall average daily gain was lower $(P<0.001)$ in IUGR piglets relative to NBW piglets. HNI increased $(P=0 \cdot 001)$ the final $\mathrm{BW}$ and $\mathrm{BW}$ gain of piglets and increased the average daily gain $(P=0.001)$, the ADMI $(P<0.001)$ and the feed conversion ratio $(P=0.003)$ throughout the experimental period. BW and NI had no interaction effect on growth performance, except for the ADMI during the 2nd week $(P=0 \cdot 021)$. Furthermore, IUGR piglets with HNI had a similar average daily gain to NBW piglets receiving ANI due to the similar ADMI throughout the experimental period.

\section{Organ indices}

As shown in Table 4, BW $(P<0.001)$ and NI $(P=0.005)$ had a significant effect on the intestinal length:BW ratio in piglets. HNI decreased $(P=0.005)$ the relative intestinal length but increased $(P=0.096)$ the relative liver weight. The relative intestinal weight $(P=0.002)$, intestinal length $(P<0.001)$, liver weight $(P<0.001)$ and pancreas weight $(P=0.023)$ of IUGR piglets were significantly higher than those of NBW piglets. The relative intestinal weight, intestinal length and liver weight of IUGR piglets with HNI were increased $(P<0.05)$ by $27 \cdot 8,15 \cdot 3$ and $29 \cdot 3 \%$ than those of NBW piglets with

Table 4. Effects of the level of nutrient intake on the organ indices of intra-uterine growth-retarded (IUGR) and normal-birth weight (NBW) neonates

(Mean values with their standard errors)

\begin{tabular}{|c|c|c|c|c|c|c|c|c|}
\hline \multirow[b]{2}{*}{ Parameters } & \multicolumn{2}{|c|}{ ANI } & \multicolumn{2}{|c|}{$\mathrm{HNI}$} & \multirow[b]{2}{*}{ SEM } & \multicolumn{3}{|c|}{$P$} \\
\hline & IUGR & NBW & IUGR & NBW & & BW & $\mathrm{NI}$ & $\mathrm{BW} \times \mathrm{NI}$ \\
\hline Intestinal weight:BW (\%) & $6 \cdot 08^{b}$ & $4 \cdot 75^{a}$ & $6.07^{b}$ & $5.03^{\mathrm{a}}$ & 0.75 & 0.002 & 0.687 & 0.659 \\
\hline Intestinal length:BW $(\mathrm{cm} / \mathrm{kg})$ & $170^{c}$ & $124^{a}$ & $143^{b}$ & $112^{\mathrm{a}}$ & 13 & $<0.001$ & 0.005 & 0.235 \\
\hline Liver weight:BW (\%) & $3 \cdot 26^{\mathrm{b}}$ & $2 \cdot 63^{\mathrm{a}}$ & $3 \cdot 40^{\mathrm{b}}$ & $2 \cdot 82^{\mathrm{a}}$ & 0.21 & $<0.001$ & 0.096 & 0.774 \\
\hline Spleen weight:BW (\%) & 0.22 & 0.19 & 0.19 & 0.21 & 0.05 & 0.801 & 0.671 & $0 \cdot 181$ \\
\hline Kidney weight:BW (\%) & 0.40 & 0.37 & 0.40 & 0.40 & 0.06 & 0.368 & 0.596 & 0.669 \\
\hline Pancreas weight:BW (\%) & 0.25 & 0.20 & 0.24 & 0.20 & 0.04 & 0.023 & 0.903 & 0.799 \\
\hline
\end{tabular}

$\mathrm{ANI}$, adequate nutrient intake; HNI, high nutrient intake; BW, body weight; NI, nutrient intake.

${ }_{a, b, c}$ Mean values within a row with unlike superscript letters were significantly different $(P<0.05)$. 
Table 5. Effects of the level of nutrient intake on the count and percentage of blood leucocytes, neutrophils, lymphocytes and monocytes in intra-uterine growth-retarded (IUGR) and normal-birth weight (NBW) neonates (Mean values with their standard errors)

\begin{tabular}{|c|c|c|c|c|c|c|c|c|c|}
\hline \multirow[b]{2}{*}{ Parameters } & \multicolumn{2}{|c|}{ ANI } & \multicolumn{2}{|c|}{$\mathrm{HNI}$} & \multirow[b]{2}{*}{ SEM } & \multicolumn{4}{|c|}{$P$} \\
\hline & IUGR & NBW & IUGR & NBW & & BW & $\mathrm{NI}$ & $\mathrm{BW} \times \mathrm{NI}$ & Time \\
\hline \multicolumn{10}{|c|}{ Leucocytes ( $10^{9} /$ litre) } \\
\hline Day 14 & $18 \cdot 30$ & $12 \cdot 16$ & $10 \cdot 65$ & 13.48 & $4 \cdot 83$ & 0.766 & 0.976 & 0.064 & 0.005 \\
\hline Day 21 & $9 \cdot 70$ & $8 \cdot 71$ & $11 \cdot 83$ & $8 \cdot 70$ & 3.50 & & & & \\
\hline \multicolumn{10}{|c|}{ Neutrophils ( $10^{9} /$ litre) } \\
\hline Day 14 & $8 \cdot 13^{b}$ & $3 \cdot 10^{\mathrm{a}}$ & $2 \cdot 07^{\mathrm{a}}$ & $1 \cdot 31^{\mathrm{a}}$ & $2 \cdot 18$ & 0.111 & 0.250 & 0.264 & 0.006 \\
\hline Day 21 & 2.99 & 1.80 & $2 \cdot 14$ & 2.95 & 1.92 & & & & \\
\hline \multicolumn{10}{|c|}{ Lymphocytes ( $10^{9} /$ litre) } \\
\hline Day 14 & 9.83 & 8.96 & $9 \cdot 29$ & 11.06 & $4 \cdot 18$ & 0.204 & 0.476 & 0.142 & 0.003 \\
\hline Day 21 & $6 \cdot 62$ & $6 \cdot 72$ & 9.42 & 5.57 & 2.95 & & & & \\
\hline \multicolumn{10}{|c|}{ Monocytes ( $10^{9} /$ litre) } \\
\hline Day 14 & 0.15 & 0.12 & 0.09 & 0.07 & 0.06 & 0.240 & 0.186 & 0.384 & 0.002 \\
\hline Day 21 & $0 \cdot 17$ & 0.31 & 0.30 & 0.21 & 0.15 & & & & \\
\hline \multicolumn{10}{|c|}{ Neutrophils (\%) } \\
\hline Day 14 & $41.90^{\mathrm{b}}$ & $27 \cdot 05^{a, b}$ & $17 \cdot 53^{\mathrm{a}}$ & $15 \cdot 05^{\mathrm{a}}$ & $12 \cdot 89$ & 0.115 & 0.015 & 0.237 & 0.003 \\
\hline Day 21 & $29 \cdot 35$ & 19.63 & $19 \cdot 18$ & 29.03 & $16 \cdot 59$ & & & & \\
\hline \multicolumn{10}{|c|}{ Lymphocytes (\%) } \\
\hline Day 14 & $56 \cdot 53^{\mathrm{a}}$ & $72 \cdot 02^{a, b}$ & $80 \cdot 30^{b}$ & $84 \cdot 32^{\mathrm{b}}$ & $12 \cdot 55$ & 0.161 & 0.018 & $0 \cdot 180$ & 0.003 \\
\hline Day 21 & $69 \cdot 45$ & 78.33 & 77.83 & 68.88 & $17 \cdot 52$ & & & & \\
\hline \multicolumn{10}{|c|}{ Monocytes (\%) } \\
\hline Day 14 & 0.80 & 0.93 & 0.77 & 0.65 & 0.26 & 0.145 & $0 \cdot 198$ & 0.259 & 0.003 \\
\hline Day 21 & 1.63 & $3 \cdot 30$ & 3.00 & 2.08 & 1.31 & & & & \\
\hline
\end{tabular}

$\mathrm{ANI}$, adequate nutrient intake; $\mathrm{HNI}$, high nutrient intake; BW, body weight; $\mathrm{NI}$, nutrient intake.

${ }^{a, b}$ Mean values within a row with unlike superscript letters were significantly different $(P<0.05)$.

ANI, respectively. However, the relative weights of the spleen and kidney were not affected by IUGR or NI. No interaction was found between BW and NI for any of the relative weights of the organs.

\section{Composition of peripheral leucocytes}

No effect of BW or the interaction between BW and NI was observed on the count or percentage of neutrophils, lymphocytes and monocytes (Table 5). HNI significantly decreased $(P=0.015)$ neutrophil percentage, but increased $(P=0 \cdot 018)$ lymphocyte percentage. The counts of leucocytes $(P=0.005)$, neutrophils $(P=0.006)$ and lymphocytes $(P=0.003)$ were decreased on day 21 . However, the count $(P=0.002)$ and percentage $(P=0.003)$ of monocytes were increased on day 21. In addition, the neutrophil count of IUGR piglets with ANI was increased $(P<0.05)$ by $163 \%$ compared with that of NBW piglets receiving HNI on day 14.

Table 6. Effects of the level of nutrient intake on the concentrations of TNF- $\alpha, \mathrm{IL}-1 \beta$ and IL-10 in intra-uterine growthretarded (IUGR) and normal-birth weight (NBW) neonates

(Mean values with their standard errors)

\begin{tabular}{|c|c|c|c|c|c|c|c|c|c|}
\hline \multirow[b]{2}{*}{ Parameters } & \multicolumn{2}{|c|}{ ANI } & \multicolumn{2}{|c|}{$\mathrm{HNI}$} & \multirow[b]{2}{*}{ SEM } & \multicolumn{4}{|c|}{$P$} \\
\hline & IUGR & NBW & IUGR & NBW & & BW & $\mathrm{NI}$ & $\mathrm{BW} \times \mathrm{NI}$ & Time \\
\hline \multicolumn{10}{|c|}{ TNF- $\alpha(p g / m l)$} \\
\hline Day 14 & $92 \cdot 3^{a, b}$ & $99 \cdot 5^{\mathrm{b}}$ & $91 \cdot 4^{\mathrm{a}}$ & $97 \cdot 4^{a, b}$ & $5 \cdot 3$ & 0.002 & 0.072 & 0.53 & 0.011 \\
\hline Day 21 & $100 \cdot 6^{a}$ & $110 \cdot 1^{\mathrm{b}}$ & $95 \cdot 3^{\mathrm{a}}$ & $99.9^{\mathrm{a}}$ & 5.5 & & & & \\
\hline \multicolumn{10}{|l|}{$\mathrm{IL}-1 \beta(\mathrm{pg} / \mathrm{ml})$} \\
\hline Day 14 & $215 \cdot 1^{a}$ & $237.6^{\mathrm{b}}$ & $212 \cdot 0^{a}$ & $223 \cdot 8^{a}$ & $10 \cdot 0$ & $<0.001$ & 0.045 & 0.711 & 0.010 \\
\hline Day 21 & $245 \cdot 3^{a}$ & $269 \cdot 2^{\mathrm{b}}$ & $237.0^{a}$ & $258 \cdot 7^{\mathrm{b}}$ & $10 \cdot 1$ & & & & \\
\hline \multicolumn{10}{|l|}{ IL-10 (pg/ml) } \\
\hline Day 14 & $113.0^{\mathrm{b}}$ & $98 \cdot 4^{\mathrm{a}}$ & $115 \cdot 0^{\mathrm{b}}$ & $121.9^{b}$ & 9.9 & 0.202 & $<0.001$ & 0.002 & 0.004 \\
\hline Day 21 & $121 \cdot 6^{\mathrm{b}}$ & $107 \cdot 1^{\mathrm{a}}$ & $124 \cdot 9^{\mathrm{b}}$ & $130 \cdot 6^{\mathrm{b}}$ & $9 \cdot 4$ & & & & \\
\hline \multicolumn{10}{|l|}{ TNF- $\alpha: I L-10$} \\
\hline Day 14 & $0.82^{a}$ & $1.02^{\mathrm{b}}$ & $0.80^{a}$ & $0.80^{\mathrm{a}}$ & 0.07 & $<0.001$ & $<0.001$ & $<0.001$ & 0.002 \\
\hline Day 21 & $0.83^{a}$ & $1.03^{\mathrm{b}}$ & $0.77^{a}$ & $0.77^{\mathrm{a}}$ & 0.05 & & & & \\
\hline \multicolumn{10}{|l|}{ IL-1 $\beta: I L-10$} \\
\hline Day 14 & $1.92^{\mathrm{a}}$ & $2.43^{\mathrm{b}}$ & $1.86^{\mathrm{a}}$ & $1.85^{\mathrm{a}}$ & 0.19 & $<0.001$ & $<0.001$ & $<0.001$ & 0.002 \\
\hline Day 21 & $2.04^{a}$ & $2.53^{\mathrm{b}}$ & $1.91^{\mathrm{a}}$ & $1.99^{\mathrm{a}}$ & 0.20 & & & & \\
\hline
\end{tabular}

$\mathrm{ANI}$, adequate nutrient intake; HNI, high nutrient intake; BW, body weight; NI, nutrient intake.

${ }_{\mathrm{a}, \mathrm{b}}$ Mean values within a row with unlike superscript letters were significantly different $(P<0.05)$. 
Table 7. Effects of the level of nutrient intake on the intestinal morphology of intra-uterine growth-retarded (IUGR) and normal-birth weight (NBW) neonates

(Mean values with their standard errors)

\begin{tabular}{|c|c|c|c|c|c|c|c|c|c|}
\hline \multirow[b]{2}{*}{ Parameters } & \multicolumn{2}{|c|}{ ANI } & \multicolumn{2}{|c|}{$\mathrm{HNI}$} & \multirow[b]{2}{*}{ SEM } & \multicolumn{4}{|c|}{$P$} \\
\hline & IUGR & NBW & IUGR & NBW & & BW & $\mathrm{NI}$ & $\mathrm{BW} \times \mathrm{NI}$ & Segment \\
\hline \multicolumn{10}{|c|}{ Villous height $(\mu \mathrm{m})$} \\
\hline Duodenum & $708^{a, b}$ & $617^{a}$ & $665^{a, b}$ & $759^{b}$ & 70 & 0.112 & 0.741 & 0.001 & 0.002 \\
\hline Jejunum & $406^{a}$ & $487^{\mathrm{C}}$ & $471^{b, c}$ & $431^{a, b}$ & 44 & & & & \\
\hline Ileum & $407^{a}$ & $525^{\mathrm{c}}$ & $491^{\mathrm{b}, \mathrm{c}}$ & $452^{b}$ & 76 & & & & \\
\hline \multicolumn{10}{|c|}{ Crypt depth $(\mu \mathrm{m})$} \\
\hline Duodenum & $172^{\mathrm{a}, \mathrm{b}}$ & $160^{\mathrm{a}}$ & $189^{b}$ & $158^{\mathrm{a}}$ & 37 & 0.477 & 0.353 & 0.077 & 0.013 \\
\hline Jejunum & $93^{a}$ & $102^{a, b}$ & $109^{b}$ & $98^{a, b}$ & 19 & & & & \\
\hline Ileum & $112^{\mathrm{a}}$ & $117^{\mathrm{a}}$ & $135^{\mathrm{b}}$ & $108^{a}$ & 27 & & & & \\
\hline \multicolumn{10}{|l|}{ VCR } \\
\hline Duodenum & $4 \cdot 32^{a, b}$ & $4 \cdot 02^{a}$ & $3.66^{\mathrm{a}}$ & $4 \cdot 82^{b}$ & $1 \cdot 20$ & 0.038 & 0.388 & 0.779 & 0.002 \\
\hline Jejunum & 4.49 & 4.85 & 4.40 & 4.47 & 0.97 & & & & \\
\hline Ileum & $3.86^{a}$ & $4 \cdot 70^{\mathrm{b}}$ & $3.78^{a}$ & $4 \cdot 23^{a, b}$ & 0.91 & & & & \\
\hline
\end{tabular}

$\mathrm{ANI}$, adequate nutrient intake; HNI, high nutrient intake; BW, body weight; NI, nutrient intake; VCR, villous height:crypt depth ratio. ${ }^{a, b, c}$ Mean values within a row with unlike superscript letters were significantly different $(P<0.05)$.

\section{Serum concentrations of TNF- $\alpha, I L-1 \beta$ and IL-10}

As shown in Table 6, IUGR decreased serum concentrations of TNF- $\alpha(P=0.002)$ and IL-1 $\beta(P<0 \cdot 001)$, as well as the ratios of TNF- $\alpha$ :IL-10 $(P<0 \cdot 001)$ and IL-1 $\beta$ :IL-10 $(P<0 \cdot 001)$ in piglets. HNI increased the concentration of IL-10 $(P<0.001)$ but decreased IL-1 $\beta$ concentration $(P=0.045)$, as well as the ratios of TNF- $\alpha$ :IL-10 $(P<0 \cdot 001)$ and IL-1 $\beta$ :IL-10 $(P<0 \cdot 001)$. BW and NI had significant interaction effects on IL-10 concentration $(P=0.002)$, as well as on the ratios of TNF- $\alpha$ :IL-10 $(P<0.001)$ and IL-1 $\beta$ :IL-10 $(P<0 \cdot 001)$. The concentrations of TNF- $\alpha(P=0 \cdot 011), \quad \mathrm{IL}-1 \beta(P=0 \cdot 010)$ and IL-10 $(P=0 \cdot 004)$ as well as the IL-1 $\beta$ :IL-10 ratio $(P=0.002)$ were higher on day 21 compared with those on day 14 . However, the TNF- $\alpha$ :IL10 ratio $(P=0.002)$ decreased on day 21 .

\section{Intestinal morphology}

Irrespective of the NI, IUGR decreased $(P=0.038)$ the intestinal villous height:crypt depth ratio (VCR) in piglets (Table 7).
No effect of NI was observed on intestinal morphology. BW and NI had a significant interaction effect on villous height $(P=0.001)$. The villous height $(P=0.002)$, the crypt depth $(P=0.013)$ and the VCR $(P=0.002)$ were significantly affected by the segment in the small intestine, with the duodenum having the highest villous height and the deepest crypt depth and the jejunum having the highest VCR. Furthermore, compared with NBW piglets receiving ANI, the duodenal and ileal crypt depths were deeper $(15-18 \%, P<0.05)$, but the ileal VCR was higher $(-20 \%, P<0.05)$ in IUGR piglets receiving HNI, respectively.

\section{Gene expression in the ileum}

The mRNA abundance of Toll-like receptor (TLR)-4 ( $P=0.039), T L R-9(P=0.003)$, TNF receptor-associated factor $6(T R A F-6, P=0.034), I L-1 \beta(P=0.021)$ and Toll-interacting protein (TOLLIP, $P=0.053$ ) was decreased in the ileum of IUGR piglets relative to NBW piglets (Table 8). HNI decreased

Table 8. Effects of the level of nutrient intake on the mRNA abundance of innate immune-related genes in the ileum of intra-uterine growth-retarded (IUGR) and normal-birth weight (NBW) neonates (Mean values with their standard errors)

\begin{tabular}{|c|c|c|c|c|c|c|c|c|}
\hline \multirow[b]{2}{*}{ Genes } & \multicolumn{2}{|c|}{ ANI } & \multicolumn{2}{|c|}{$\mathrm{HNI}$} & \multirow[b]{2}{*}{ SEM } & \multicolumn{3}{|c|}{$P$} \\
\hline & IUGR & NBW & IUGR & NBW & & BW & $\mathrm{NI}$ & $\mathrm{BW} \times \mathrm{NI}$ \\
\hline TLR-2 & 1.02 & 1.25 & 1.31 & 1.14 & 0.44 & 0.864 & 0.580 & 0.226 \\
\hline$T L R-4$ & $1.04^{\mathrm{a}, \mathrm{b}}$ & $1.42^{\mathrm{b}}$ & $0.76^{a}$ & $1 \cdot 23^{a, b}$ & 0.38 & 0.039 & 0.231 & 0.841 \\
\hline$T L R-9$ & $1 \cdot 26^{a}$ & $1 \cdot 28^{a}$ & $1 \cdot 16^{\mathrm{a}}$ & $3.96^{b}$ & 1.26 & 0.003 & 0.005 & 0.003 \\
\hline MyD88 & $1 \cdot 10$ & 1.09 & 0.72 & 1.25 & 0.46 & 0.214 & 0.585 & 0.201 \\
\hline TRAF-6 & 1.09 & 2.09 & 1.23 & 1.90 & 0.97 & 0.034 & 0.938 & 0.651 \\
\hline$N F-\kappa B$ & $1.07^{a, b}$ & $1 \cdot 23^{b}$ & $0.78^{a}$ & $0.85^{a, b}$ & 0.30 & 0.421 & 0.034 & 0.763 \\
\hline SIGIRR & $1 \cdot 16$ & 1.08 & 0.81 & 0.83 & 0.47 & 0.891 & 0.112 & 0.780 \\
\hline TOLLIP & $1.07^{\mathrm{a}}$ & $1.59^{b}$ & $1.03^{\mathrm{a}}$ & $1 \cdot 13^{\mathrm{a}}$ & 0.46 & 0.053 & 0.114 & 0.182 \\
\hline$I L-1 \beta$ & 1.04 & 1.37 & 0.71 & 1.02 & 0.26 & 0.021 & 0.015 & 0.937 \\
\hline
\end{tabular}


the mRNA abundance of $N F-\kappa B(P=0.034)$ and $I L-1 \beta$ ( $P=0 \cdot 015)$, but increased TLR-9 $(P=0.005)$ mRNA expression in the ileum. BW and NI had no interaction effect on the mRNA abundance of these genes in the ileum, except for TLR-9 ( $P=0.003)$. Moreover, IUGR piglets receiving HNI had a lower $(P<0.05)$ mRNA abundance of TLR-4,NF- $K B$ and TOLLIP in the ileum than NBW piglets receiving ANI.

\section{Discussion}

The present study was one of the rare studies documenting the effect of HNI during the suckling period on the growth and immune function of IUGR piglets reared in wellcontrolled conditions. The intriguing findings were that IUGR piglets exhibited a differential immune response to HNI compared with NBW piglets. Particularly, the increased NI during the $21 \mathrm{~d}$ of the suckling period impaired the systematic immune response of IUGR piglets by decreasing the number of leucocytes, altering the serum cytokine profile and the intestinal expression of innate immune-related genes.

The lower BW gain in IUGR pigs could be resulting from the inadequate intake of nutrients, as indicated by the markedly decreased average DM intake in IUGR pigs. However, IUGR pigs are able to exert a similar growth rate to normal pigs when receiving a similar DM intake. The present results showed that there was a comparable BW gain between the IUGR pigs with HNI and NBW pigs with ANI. These findings indicate that IUGR piglets receiving HNI achieved catch-up growth. The difference in the BW of piglets was due to the ADMI and the corresponding different nutrient contents of the formula milk.

IUGR could lead to a relatively longer intestine in neonates, as previously described in pigs ${ }^{(22)}$, rabbits ${ }^{(23)}$ and sheep ${ }^{(24)}$. In the present study, consistently, IUGR piglets exhibited a relatively longer intestine and a heavier liver and pancreas, indicating the potential metabolic priority over key organs relative to whole-body growth ${ }^{(25,26)}$. The liver plays a major role in the metabolism of dietary nutrients and other substances $^{(27)}$. The higher relative liver weight in IUGR piglets with HNI may presumably be due to the compensatory hypertrophy of the liver, which is in accordance with the report of Rompala et al. ${ }^{(28)}$ showing that rams with a high level of feed intake resulted in a greater liver weight:empty BW ratio.

Growth rate was increased in IUGR piglets receiving HNI. However, it seems that catch-up growth would impair the immune system according to the results of serum cytokines. The neonatal period was the intense period of changes in the expression of molecules involved in the recognition of bacteria by epithelial and immune cells, such as TLR and cytokines $^{(11)}$. Cytokine concentrations and their ratios were sharply changed in IUGR piglets with HNI relative to NBW piglets, which suggested the compromised immune function of piglets.

In addition, during the neonatal period, cells of the innate immune system, predominantly neutrophils, macrophages and natural killer cells, are mainly responsible for the clearance of foreign antigens. In neonates, cells involved in triggering innate immunity are functional, but they are present in lower numbers and have lower enzyme activity than their adult counterparts ${ }^{(29)}$. In the present study, we did not test macrophages and natural killer cells, but the number and percentage of neutrophils were decreased along with the increase of lymphocyte percentage in IUGR piglets receiving HNI on day 14 . As the events in the neonatal period allow the maturation of the immune system, peripheral lymphocyte subsets also showed certain changes. Comans-Bitter et al. ${ }^{(30)}$ and de Vries et al. ${ }^{(31)}$ found that an increase in T- and B-lymphocytes occurred during the 1st weeks of life, while natural killer cells declined after birth $^{(30,31)}$

Small-intestinal morphology containing the villous height, the crypt depth and the VCR of the duodenum, jejunum and ileum is one of the major indicators reflecting gut health in piglets. The increasing villous height implied the increased surface area for nutrient absorption ${ }^{(32)}$, whereas the deeper crypt suggested a fast new villous tissue turnover in response to normal sloughing or inflammation from a pathogen ${ }^{(33)}$. In the present study, IUGR piglets with HNI had higher jejunal and ileal villous heights, compared with piglets with ANI, which could be an important reason for the catch-up growth. However, the jejunal and ileal crypt depths in IUGR piglets receiving HNI were deeper. The present results are consistent with a previous study which suggested that piglets with a high level of feed intake had a higher villous height and a deeper crypt depth ${ }^{(34)}$

Moreover, the gastrointestinal tract is the largest immune organ in the body, and, as such, is the location for the majority of lymphocytes and immune effector cells with pattern recognition receptors ${ }^{(35)}$, which sense luminal antigens and mediate the inflammatory response ${ }^{(36)}$. TLR are typical pattern recognition receptors in mediating mucosal innate host defence and in maintaining mucosal and commensal homeostasis ${ }^{(36)}$. MyD88, TRAF-6 and NF- $\mathrm{B}$ are downstream signalling molecules and transcription factors shared by TLR-2, -4 and $-9^{(37)}$, while single Ig IL-1-related receptor and TOLLIP are crucial negative regulators ${ }^{(38)}$. It has been demonstrated that the TLR-4-Myd88-NF-кB signal pathway is involved in inflammation ${ }^{(39)}$. Nenci et al. ${ }^{(40)}$ suggested that the downregulation of $N F-\kappa B$ at the mRNA level might be a regulatory mechanism to augment long-term inflammatory responses. The decreased expressions of TLR-4, TLR-9, NF- $\kappa B$ and $I L-1 \beta$ in IUGR piglets receiving HNI suggested that HNI during the suckling period would reduce the intestinal innate immunity of IUGR piglets.

In summary, the present results suggest that HNI during the suckling period would lead to an abnormal immune function of neonatal piglets with IUGR. Further investigations are warranted to determine whether IUGR pigs with HNI would have a persistent impact on the immune system.

\section{Acknowledgements}

The present study was supported by the International Cooperation in Science and Technology Project of Sichuan Province (no. 2010HH0014), the National 973 Project (2012CB124701) and the National Natural Science Foundation 
(no. 31101727). F. H., Y. X., X. D., Y. L. and S. B. participated in the experimental design and data interpretation, and helped in the drafting of the manuscript. L. C. and K. Z. conceived the study, directly supervised the project and participated in the experimental design and data interpretation. F. H., S. H. and L. H. carried out the animal feeding trial and molecular experiment. F. H. was responsible for the writing of the manuscript. There are no conflicts of interest to declare.

\section{References}

1. Wu G, Bazer FW, Cudd TA, et al. (2004) Maternal nutrition and fetal development. J Nutr 134, 2169-2172.

2. de Onis M, Blossner M \& Villar J (1998) Levels and patterns of intrauterine growth retardation in developing countries. Eur J Clin Nutr 52, Suppl. 1, S5-S15.

3. Aucott SW, Donohue PK \& Northington FJ (2004) Increased morbidity in severe early intrauterine growth restriction. J Perinatol 24, 435-440.

4. Garite TJ, Clark R \& Thorp JA (2004) Intrauterine growth restriction increases morbidity and mortality among premature neonates. Am J Obstet Gynecol 191, 481-487.

5. D'Inca R, Gras-Le Guen C, Che L, et al. (2011) Intrauterine growth restriction delays feeding-induced gut adaptation in term newborn pigs. Neonatology 99, 208-216.

6. D'Inca R, Kloareg M, Gras-Le Guen C, et al. (2010) Intrauterine growth restriction modifies the developmental pattern of intestinal structure, transcriptomic profile, and bacterial colonization in neonatal pigs. $J$ Nutr $\mathbf{1 4 0}$, 925-931.

7. Cromi A, Ghezzi F, Raffaelli R, et al. (2009) Ultrasonographic measurement of thymus size in IUGR fetuses: a marker of the fetal immunoendocrine response to malnutrition. Ultrasound Obstet Gynecol 33, 421-426.

8. Lang U, Baker RS, Khoury J, et al. (2000) Effects of chronic reduction in uterine blood flow on fetal and placental growth in the sheep. Am J Physiol Regul Integr Comp Physiol 279, R53-R59.

9. Contreras YM, Yu X, Hale MA, et al. (2011) Intrauterine growth restriction alters T-lymphocyte cell number and dual specificity phosphatase 1 levels in the thymus of newborn and juvenile rats. Pediatr Res 70, 123-129.

10. Zhong X, Li W, Huang X, et al. (2012) Impairment of cellular immunity is associated with overexpression of heat shock protein 70 in neonatal pigs with intrauterine growth retardation. Cell Stress Chaperones 17, 495-505.

11. Chatelais L, Jamin A, Gras-Le Guen C, et al. (2011) The level of protein in milk formula modifies ileal sensitivity to LPS later in life in a piglet model. PLoS One 6, e19594.

12. Premji S, Fenton $T$ \& Sauve $R$ (2006) Higher versus lower protein intake in formula-fed low birth weight infants. The Cochrane Database of Systematic Reviews issue 1, CD003959.

13. Young L, Morgan J, McCormick FM, et al. (2012) Nutrientenriched formula versus standard term formula for preterm infants following hospital discharge. The Cochrane Database of Systematic Reviews issue 3, CD004696.

14. Stettler N, Stallings VA, Troxel AB, et al. (2005) Weight gain in the first week of life and overweight in adulthood: a cohort study of European American subjects fed infant formula. Circulation 111, 1897-1903.

15. Guo YL, Li WB \& Chen JL (2010) Influence of nutrient density and lighting regime in broiler chickens: effect on antioxidant status and immune function. Br Poult Sci $\mathbf{5 1}$, $222-228$.

16. Jang I, Kang S, Ko Y, et al. (2009) Effect of qualitative and quantitative feed restriction on growth performance and immune function in broiler chickens. Asian-Aust J Anim Sci 22, 388-395.

17. Humphray SJ, Scott CE, Clark R, et al. (2007) A high utility integrated map of the pig genome. Genome Biol 8, R139.

18. Wu G, Bazer FW, Wallace JM, et al. (2006) Board-invited review: intrauterine growth retardation: implications for the animal sciences. J Anim Sci 84, 2316-2337.

19. Dourmad JY, Noblet J \& Etienne M (1998) Effect of protein and lysine supply on performance, nitrogen balance, and body composition changes of sows during lactation. J Anim Sci 76, 542-550.

20. Che L, Thymann T, Bering SB, et al. (2010) IUGR does not predispose to necrotizing enterocolitis or compromise postnatal intestinal adaptation in preterm pigs. Pediatr Res $\mathbf{6 7}$, 54-59.

21. Livak KJ \& Schmittgen TD (2001) Analysis of relative gene expression data using real-time quantitative PCR and the 2(-Delta Delta $C(\mathrm{~T}))$ method. Methods 25, 402-408.

22. Xu RJ, Mellor DJ, Birtles MJ, et al. (1994) Impact of intrauterine growth retardation on the gastrointestinal tract and the pancreas in newborn pigs. J Pediatr Gastroenterol Nutr 18, 231-240.

23. Cellini C, Xu J, Arriaga A, et al. (2004) Effect of epidermal growth factor infusion on fetal rabbit intrauterine growth retardation and small intestinal development. I Pediatr Surg 39, 891-897.

24. Avila CG, Harding R, Rees S, et al. (1989) Small intestinal development in growth-retarded fetal sheep. J Pediatr Gastroenterol Nutr 8, 507-515.

25. Bauer R, Walter B, Hoppe A, et al. (1998) Body weight distribution and organ size in newborn swine (sus scrofa domestica) - a study describing an animal model for asymmetrical intrauterine growth retardation. Exp Toxicol Pathol 50, 59-65.

26. Mostyn A, Litten JC, Perkins KS, et al. (2005) Influence of size at birth on the endocrine profiles and expression of uncoupling proteins in subcutaneous adipose tissue, lung, and muscle of neonatal pigs. Am J Physiol Regul Integr Comp Physiol 288, R1536-R1542.

27. Jobgen WS, Fried SK, Fu WJ, et al. (2006) Regulatory role for the arginine-nitric oxide pathway in metabolism of energy substrates. J Nutr Biochem 17, 571-588.

28. Rompala RE, Johnson DE, Rumpler WV, et al. (1991) Energy utilization and organ mass of Targhee sheep selected for rate and efficiency of gain and receiving high and low planes of nutrition. J Anim Sci 69, 1760-1765.

29. Kovarik J \& Siegrist CA (1998) Immunity in early life. Immunol Today 19, 150-152.

30. Comans-Bitter WM, de Groot R, van den Beemd R, et al. (1997) Immunophenotyping of blood lymphocytes in childhood. Reference values for lymphocyte subpopulations. J Pediatr 130, 388-393.

31. de Vries E, de Bruin-Versteeg S, Comans-Bitter WM, et al. (2000) Longitudinal survey of lymphocyte subpopulations in the first year of life. Pediatr Res 47, 528-537.

32. Caspary WF (1992) Physiology and pathophysiology of intestinal absorption. Am J Clin Nutr 55, 299S-308S.

33. Yason CV, Summers BA \& Schat KA (1987) Pathogenesis of rotavirus infection in various age groups of chickens and turkeys: pathology. Am J Vet Res 48, 927-938. 
34. van Beers-Schreurs HM, Nabuurs MJ, Vellenga L, et al. (1998) Weaning and the weanling diet influence the villous height and crypt depth in the small intestine of pigs and alter the concentrations of short-chain fatty acids in the large intestine and blood. $J$ Nutr 128, 947-953.

35. Kelly D \& Coutts AG (2000) Early nutrition and the development of immune function in the neonate. Proc Nutr Soc 59, $177-185$.

36. Newburg DS \& Walker WA (2007) Protection of the neonate by the innate immune system of developing gut and of human milk. Pediatr Res 61, 2-8.
37. Takeda K \& Akira S (2004) TLR signaling pathways. Semin Immunol 16, 3-9.

38. Shibolet O \& Podolsky DK (2007) TLRs in the gut. IV. Negative regulation of toll-like receptors and intestinal homeostasis: addition by subtraction. Am J Physiol Gastrointest Liver Physiol 292, G1469-G1473.

39. Kawai T \& Akira S (2009) The roles of TLRs, RLRs and NLRs in pathogen recognition. Int Immunol 21, 317-337.

40. Nenci A, Becker C, Wullaert A, et al. (2007) Epithelial NEMO links innate immunity to chronic intestinal inflammation. Nature 446, 557-561. 